\title{
LU 79. STARPTAUTISKĀS ZINĀTNISKĀS KONFERENCES SEKCIJA “ARHEOLOGU UN ETNOGRĀFU PĒTİJUMI LATVIJĀ 2018.-2020. GADĀ”
}

2021. gada 11. martā Latvijas Universitātes 79. starptautiskās zinātniskās konferences ietvaros LU Latvijas vēstures institūts (turpmāk LU LVI) organizēja sekciju "Arheologu un etnogrāfu pētījumi Latvijā 2018.-2020. gadā”. Sekcija bija iecerēta kā tradicionālā kopš 20. gs. 50. gadiem uzturētā arheologu un etnogrāfu atskaites sesija, jo iepriekšèjā gada pavasarī plānoto nācās atcelt pandēmijas noteikto ierobežojumu dēḷ. Mērķis bija parādīt arheologu un etnogrāfu ieguldījumu arheologiskā un tradicionālās kultūras mantojuma un senvēstures aktuālu jautājumu izpētē.

Sekcijas darbu atklāja LU LVI direktors profesors Gvido Straube. Norādot, ka doma organizēt šādu sekciju ir bijusi saprātīga, jo tas ir labs veids, kā paveikto popularizēt sabiedrībai, viņš izteica atzinību institūta arheologiem, kuru darba rezultāti ieguvuši augstu novērtējumu Latvijas zinātnisko institūciju starptautiskajā izvērtējumā.

Sekcijā tika nolasīti 13 referāti, ko bija sagatavojuši 16 pētnieki. Referāti atspoguḷoja dažādas zinātnieku darbības jomas - lauka pētījumus (apzināšanas, izrakumus), kā arī projektu ietvaros pētītas tēmas.

Arheologu apzināšanas ekspedīciju darbs tika prezentēts trīs referātos. Lai gan Latvijā pieminekḷu apzināšana bijusi arheologu uzmanības centrā jau kopš 20. gs. 20.-30. gadiem, joprojām ir teritorijas, kur ziņu par arheologiiskām senvietām atsevišķos aizvēstures periodos ir visai maz. Mūsdienu aerolāzerskenēšanas tehnologiju jeb LiDAR datu izmantošana un pārdomāta metodologija pavērusi jaunas iespējas un devusi nozīmīgus rezultātus. Jāatzīmē, ka ir paplašinājies izzināmo vietu loks - līdztekus dzīvesvietu un kapulauku meklējumiem uzsākti arī senatnē izmantoto dabas resursu un dažādu aktivitāšu vietu meklējumi.

Pēdējos gados LiDAR dati plaši izmantoti agrāk nezināmu pilskalnu atklāšanā. Mazāk zināms fakts, ka šī metode vairākus gadus sekmīgi lietota arī dzelzs laikmeta apbedījumu vietu apzināšanā Rietumvidzemē. Par lïbiešu zemes Metsepoles teritorijas 2020. gada apzi- 
nāšanas rezultātiem referēja Jānis Ciglis (Latvijas Nacionālais vēstures muzejs). Minētajā teritorijā atklātas vairākas uzkalniṇu grupas, kas norāda uz blīvāku apdzīvotību, nekā līdz šim tika uzskatīts.

Balstoties uz jau zināmo paleogéeogrāfisko datu kombinēšanu ar LiDAR datiem, paleoezera krasta linijas modelēšanu, mūsdienu ainavas un reljefa izvērtējumu, iegūti nozīmīgi dati par potenciālajām akmens laikmeta apmetņu, dabas izejvielu (māls, okers, krams) ieguves un apstrādes vietām Burtnieku ezera krastos. Šie 2020. gadā veiktās apzināšanas rezultāti tika aplūkoti Mārča Kalniņa (LU Vēstures un filozofijas fakultāte) un Aijas Macānes (Gēteborgas Universitāte) referātā. Uzsākt apzināšanu autorus rosināja līdzšinējie dati par apdzīvotību daudzus gadu tūkstošus ilgā laika periodā un salīdzinoši nelielo pieminekḷu skaitu ezera krastos.

Savukārt Vandas Visockas, Mārča Kalniṇa (LU Vēstures un filozofijas fakultāte) un Arta Kona (LU Ķīmijas fakultāte) sagatavotajā ziņojumā tika izklāstīti rezultāti, kas iegūti, pētot māla iegulu izplatību aizvēsturisko dzīvesvietu tuvumā trīs reǵionos (Burtnieku ezera apkārtne, Daugavas lejtece, Rietumkurzeme). Veikta arī māla ķīmiskā sastāva un īpašību izpēte ar dabaszinātṇu metodēm. Pirmie pētījumi parādījuši, ka ne visi seno dzīvesvietu tuvumā pieejamie māla resursi izmantoti trauku izgatavošanai.

Plaša arheologu darba joma - izrakumi. Tiesa, lielākoties tie ir t. s. komercizrakumi, kas ir izvērsto celtniecības darbu diktēti. Prezentēti tika tikai daži - zinātniskos nolūkos veiktie izrakumi. Par atklājumiem zemgaḷu apdzīvotajā teritorijā referēja Normunds Jērums (Tērvetes senvēstures muzejs). Pēc viṇa domām, jaunatklātais Tērvetes Viesturu kapulauks ar ugunskapiem devis atrisinājumu problēmai, kāpēc senajās zemgaḷu zemēs trūkst ar 12.-13. gs. datējamu apbedījumu. Tomēr rodas jautājums, vai, balstoties uz visai nelielu atklāto ugunskapu skaitu, tik viennozīmīgi secinājumi nav pāragri. Arī ugunskapos atrastās Baltijas somiem (lībiešiem, vendiem) un kuršiem raksturīgas rotas uzdod jaunus jautājumus, uz kuriem pagaidām nav skaidras atbildes.

2019. gadā vienlaikus ar mantraču postijumu sakopšanas darbiem izrakumi veikti Loginu uzkalniṇkapulaukā Ziemel̦austrumlatvijā (vad. Uldis Kalējs). Par atklājumiem šajos senkapos referēja Antonija Vilcāne (LU LVI). Šie izrakumi devuši datus par lielāku vienā uzkalniņā apbedīto skaitu, nekā līdz šim bija konstatēts. Pētot uzkalniņam 
piegulošo teritoriju, tika atklāts, ka mirušie ierakti arī starp uzkalniņiem. Lai pārliecinātos, vai šiem atklājumiem nav tikai gadījuma raksturs, nepieciešami plašāki izrakumi. Atsegtajiem apbedījumiem veiktās radioaktīvā oglekḷa $\left({ }^{14} \mathrm{C}\right)$ analīzes parādīja, ka šĩ datēšanas metode ir nozīmīga bezinventāra un postīto apbedījumu hronologijas noteikšanai.

Izrakumu laikā arvien lielāka vērība tiek pievērsta paraugu materiāla savākšanai starpdisciplinārai izpētei. Lapiṇu kapulauks ir viens no retajiem kuršu kapulaukiem, kuram veiktas sporu-putekšņu un augu makroatlieku analīzes, pēc kokoglēm noteiktas koku sugas un paraugi datēti ar ${ }^{14} \mathrm{C}$ metodi. Ar kapulauka starpdisciplināro pētījumu rezultātiem iepazīstināja Inga Doniņa (LU LVI).

Atsevišķos referātos tika prezentētas arī atziṇas, kas iegūtas, padzilināti strādājot pie kādas tēmas. Valdis Bērziņš (LU LVI) analizēja neolīta laika keramikas rotājumu veidus kopienas dzīvesveida kontekstā. Cūkdelfīna zobu iespiedumi un aptītās auklas rotājuma mikroskopiskā izpēte l̦āvusi autoram izprast ne tikai keramikas rotāšanas tehnisko pusi, bet iegūt arī netiešu un pastarpinātu informāciju par akmens laikmeta iedzīvotāju dzīvesveidu un nodarbēm.

Latvijā tikai pēdējos gados pievērsta uzmanība "bērnu arheologíjai” - pētījumiem par bērniem senatnē. Šì arheologijas nozare ietver plašu risināmo jautājumu loku, bet dažādu iemeslu dẹl to izpētes iespējas ir ierobežotas. Aijas Ērkšķ̧es (LU LVI) referātā tika izvērtētas bērnu apbedījumu analīzes iespējas gadījumos, kuros nav pieejams kaulu materiāls.

Arheologu ziņojumus noslēdza Ievas Oses (LU LVI) referāts, kurā tika aktualizēts jautājums par jauno laiku arheologiju. Atšķirībā no citām valstīm, kur jauno laiku arheologija ir atseviškła arheologijas disciplīna, Latvijā par šo periodu nav ne teorētisku pētījumu, ne apkopojošu publikāciju. Kā galvenie jauno laiku arheologijas attīstības izaicinājumi tika minēti hronolog̣isko robežu noteikšana, likumdošanas pārskatīšana un starpdisciplināru pētījumu izvēršana.

Rezumējot jāatzīmēe, ka arheologu referāti atspoguḷo jaunu tēmu un arheologiskā materiāla interpretāciju meklējumus, kā arī jaunāko tehnologiju un metožu pielietojumu. Arheologu panākumu atslēga starpdisciplinārie pētījumi un dabaszinātṇu speciālistu piesaiste izrakumos iegūtā materiāla analīzē, kas prasa gan spējas atrast sadarbības partnerus, gan arī nereti papildus finansējumu. Jāatzīmē arī, ka sekcijā nolasītie referāti parāda galvenokārt Latvijas Universitātē strādājošo 
arheologu darbu. Citu institūciju arheologu, īpaši komercarheologu, vidū jau ilgāku laiku saglabājas pasivitāte savas pieredzes, metožu un izrakumu rezultātu publiskošanā, kā arī izrakumos iegūtā materiāla padziḷinātā izpētē un publikāciju sagatavošanā.

Sekcijas programmas četri noslēdzošie referāti atspoguḷoja LU LVI pētnieku devumu etnogrāfijā. Aija Jansone un Ieva Pīgozne prezentēja pēdējos gados Latgalē organizēto etnogrāfisko ekspedīciju veikumu. Tas ietver ar tekstiliju (tostarp arī katoḷu baznīcu liturgisko tekstiliju), apgēerba un rokdarbu vēsturi saistītā materiālā un nemateriālā kultūras mantojuma izpēti. Liturğisko tekstiliju apzināšana aizsākusies pavisam nesen. Bagātīgi ilustrētie referāti parādīja tekstiliju daudzveidību, izpētes problēmas, kā arī nākotnē pētāmo jautājumu loku.

Izpratne par etnogrāfijas kā zinātṇu disciplīnas uzdevumiem dažādos laikposmos un pasaules regionos ir bijusi atšķirīga. Padomju periodā latviešu etnogrāfi pētīja tautu dzīvesveidu un kultūru, skatot to caur šķiru prizmu, bet pētījumu virzieni tika apstiprināti Maskavā. Šos jautājumus skaidroja un ieskatu padomju perioda etnogrāfu darbībā sniedza Anete Karlsone. Jāpiebilst, ka pēdējos gadu desmitos institūtā strādājošo etnogrāfu skaits ir krietni sarucis un viṇi lielākoties nodarbojas ar apgèèrba un tekstiliju vēsturi.

Etnogrāfu pētīto tēmu vidū novitāte ir etnogrāfiskie un frīku šovi Latvijā 19. un 20. gs. mijā, par kuru izpētes virzieniem referēja Ilze Boldāne-Zeḷenkova. Pētījumi par šo tēmu izvērsti Eiropas un ASV humanitārajās un sociālajās zinātnēs, bet Latvijā šie jautājumi līdz šim nav bijuši uzmanības lokā.

Šì konference savā ziṇā bija izaicinājums tās organizētājiem un referentiem, jo notika attālināti MS Teams platformā, bet ieguvums interesentu lokam. Sekcijas darba videoieraksts pieejams Latvijas vēstures institūta Facebook lapā, kas l̦auj neklātienē iepazīties ar zinātnieku veikumu. Par to, ka šì iespēja aktīvi izmantota, liecina arī vairāk nekā 2800 videoieraksta skatījumu mēneša laikā (skatīts 21.04.2021.). Nolasīto referātu tēžu apkopojums ievietots LU Repozitorijā.

Sekcija tika rīkota LU prioritārās tēmas apakšprojekta "Latvijas teritorija kā dažādu kultūrtelpu, relig̣iju, politisko, sociālo un ekonomisko interešu saskarsmes zona no aizvēstures līdz mūsdienām” (reg̣. Nr. ZD2015/AZ85) ietvaros. 


\section{SESSION "RESEARCH BY ARCHAEOLOGISTS \\ AND ETHNOGRAPHERS IN LATVIA IN 2018-2020" \\ OF THE UNIVERSITY OF LATVIA $79^{\mathrm{TH}}$ INTERNATIONAL SCHOLARLY CONFERENCE}

The conference session was organised by the Institute of Latvian History (ILH) on MS Teams platform on 11 March 2021. It continues the tradition of sessions regularly held since the 1950s in which archaeologists and ethnographers report about their research findings.

The archaeologists' presentations revealed their quest for new topics and efforts to interpret the acquired archaeological material as well as the application of the latest technologies and methods. They also demonstrate the awareness that the key to success of today's archaeologists lies in interdisciplinary studies and engagement of natural scientists in the analysis of the unearthed material.

Over the recent three years, archaeological surveys have been organised to identify the sites of activities of the ancient communities and extraction or natural resources, as well as to clarify settlement-related issues. The presentations acquainted the audience with the potential sites of Stone Age settlements and of extraction and processing of natural resources (clay, ochre, flint) on the shores of Lake Burtnieks (M. Kalniņš, A. Macāne), with identification of clay deposits and research of the chemical composition and features of clay found in the vicinity of pre-historical settlements near Lake Burtnieks, in the Lower Reaches of the River Daugava and the western part of Kurzeme region (V. Visocka, M. Kalniņš, A. Kons), as well as with the newly discovered groups of barrows in Metsepole, which formerly had been considered a scarcely populated land of the Livs (J. Ciglis). New opportunities for the survey of archaeological monuments are provided by airborne laser scanning technologies, i.e. LiDAR data.

The results of excavations in several burial grounds were also presented in the session. One of the reports focused on the researched cremation graves in the newly discovered Tērvete Viesturi burial ground (N. Jērums), while another one was dedicated to excavations in Logini barrow cemetery in Vilaka district and the results of the radiocarbon $\left({ }^{14} \mathrm{C}\right)$ analysis of the unearthed burials (A. Vilcāne). These excavations have provided an important material for the study of the Semigallian and Latgallian $12^{\text {th }}-14^{\text {th }}$ century burial traditions.

Increasing attention is attributed to the collection of sample material during fieldwork and to its interdisciplinary research. A presentation was dedicated to the analysis of spore/pollen and plant micro-remains as well as the radiocarbon $\left({ }^{14} \mathrm{C}\right)$ dating of the samples collected in Lapini burial ground $\left(12^{\text {th }}-12 / 15^{\text {th }}\right.$ centuries) in the northern part of Kurzeme region (I. Donina, V. Bērziņš, N. Stivriņš). 
Individual presentations were dedicated to topical issues in Latvian archaeology: types of decoration of Neolithic pottery in the context of the community lifestyle (V. Bērziņš); the possibilities of identifying child burials in cases when skeletal bone material is not available (A. Ërkšķe), and the problems of post-medieval archaeology in Latvia, as well as the challenges on the path of the development of this field of research here (I. Ose).

Ethnographers presented the findings of the ethnographic expeditions organised to Latgale region in the recent years, covering areas such as the research of liturgical textiles used in Catholic churches (A. Jansone) as well as the study of clothing and handicraft (I. Pìgozne). The research directions of fieldwork organised during the Soviet period and factors affecting them were also evaluated (A. Karlsone). Among the themes covered by ethnographers, a novel topic is ethnographic and freak shows in Latvia at the turn of the $20^{\text {th }}$ century (I. Boldāne-Zelienkova).

The theses of the delivered presentations are accessible at the UL Repository.

Antonija Vilcāne 